\title{
SUPERVISION - WHAT'S IN A WORD?
}

\section{$M$ van Wyk, M SocSc, RAU Project Manager, Rand Afrikaans University}

\section{E D Smith $M$ (Phys T) UP}

Physiotherapists have lived with the fallacy that supervision is a function relevant only in the management of physiotherapy assistants or other support personnel. The word supervision is derived from the Latin words "super" which means "over" and "videre" which means "see". The tendency has been to interpret supervision in this rather limited and literal way. This in turn has led to negative attitudes in both the supervisors and supervisees, towards a function which should be stimulating and challenging and to which all employees, not only support personnel, are entitled. We would like to suggest guidelines which would empower physiotherapists, in all sectors of employment, to use supervision or the collection of functions to be described as a dynamic management tool for all their employees.

\section{DEFINITIONS}

Literature reviews support the opinion that supervision is a far broader concept than the literal interpretation of "overseeing" as defined by the Oxford dictionary"

"Supervision is the process concerned with helping staff members to use their knowledge and skills in doing their job efficiently and effectively"2.

"...a supervisor is an agency administrative staff member to whom authority is delegated to direct, coordinate, enhance and evaluate the on-the-job performance of the supervisees for whose work he is accountable ${ }^{\prime 3, p 24}$.

"Supervision may be envisaged as a two way street in which a positive relationship is build upon the supervisor's creative blend of the administrative, educational and supportive functions and the social workers creative use of supervision in order to deliver the best possible services to the clients ${ }^{\prime \prime}$.

\section{SUMMARY}

The importance of supervision is highlighted and reference is made to the fact that a negative attitude, lack of training and lack of experience can seriously hamper the successful implementation of supervision. Supervision, can be very challenging and stimulating and can prove to be of tremendous value to the manager, worker, patient, student and the organisation. There is much more to supervision than merely "overseeing" and it includes multiple aspects of personnel management which, when executed well, can lead to quality services being rendered and job satisfaction. The diversity of roles required from the supervisor necessitates specific training in the skills and competencies.

\section{OPSOMMING}

Die noodsaaklikheid van supervisie word beklemtoon en uitgewys dat die bestaande negatiewe houding teenoor supervisie die suksesvolle implementering daarvan belemmer. Wanneer supervisie reg aangepak word, is dit uitdagend en stimulerend met baie waarde vir die bestuurder, werker, pasiënt, student en organisasie. Supervisie is veel meer as net toesighouding, dit behels veelvuldige aspekte van personeelbestuur wat, indien dit uitstekend uitgevoer word, kan lei tot kwaliteitsdienslewering en werksbevrediging. Weens die verskeidendeid rolle wat van die supervisor vereis word, behoort spesifieke opleiding in die kundighede en vaardighede van supervisie aangebied te word.
"A supervisor is a first-level manager who accomplishes work with and through subordinates. He or she directs the work activities of the people..." ${ }^{5}$.

"Supervision is the function of leading, coordinating and directing the work of others to accomplish designated objectives" 6 .

From the above definitions it is clear that supervision encompasses tasks such as directing, coordinating, evaluating, educating and supporting of employees which are comparable to the tasks of personnel management. Skidmore's definition provides us with a solid motivation for embarking on a structured supervisory process which can be depicted as follows:

Structured supervision $\rightarrow$

efficient and effective performances of staff members $\rightarrow$ job satisfaction

This process clearly indicates the positive value and connotation that supervision can have for both the supervisee and the organisation.

The literature reviewed for this article is heavily biased towards the social work professionals as they appear to be the only group of health professionals who have developed a scientific body of knowledge on supervision. A Medline search revealed only one relevant reference to this article. The elements of supervision however constitute generic managerial tasks which are essential to any profession including physiotherapy.

Within physiotherapy, the only definition of supervision that is documented, is that promulgated by the SAMDC and which states that "Supervision means the acceptance of liability for the acts of another practitioner" ${ }^{\prime 7}$. In the context of this Gazette, the term supervision refers to the legal liability physiotherapists have in respect of the practice of physiotherapy assistants.

We believe that physiotherapists have accepted their legal responsibility towards assistants, but only in the limited and literal context of "overseeing" of assistants, rather than being aware of the exciting possibilities of the comprehensive process of supervising all subordinates including students.

The literature reviewed mainly referred to the person receiving supervision as the supervisee and to a lesser extent as the subordinate. To stay in line with the available literature, this article will refer mostly to supervisees

\section{GOALS AND FUNCTIONS OF SUPERVISION}

The comprehensive process of supervision starts with clear goals which are acceptable to both the supervisor and supervisee. Being in a helping profession, the following goals could be acceptable:

- To provide patients with the best possible service

- To improve an employee's capacity to do his/her job more effectively

- To enhance an employee's professional growth and development

- To lead physiotherapy students and junior physiotherapists to professional independence

It is important to note that the goals of supervision should correspond with the goals of the organisation. A supervisor forms the first line in the management chain as he or she directs and controls the activities of subordinates in achieving the goals of the organisation ${ }^{6}$. 
Presently supervision is also being recognised as a means of maintaining and developing quality. With the current movement of decentralisation of authority with concomitant greater autonomy for workers the tendency is to negate functions like supervision. However, strong views are expressed that "the transfer of autonomy to, or within hospitals and district health services, should never be absolute. Health professionals, managers and workers have to be supervised to ensure that they work within the appropriate policy, professional, legal and ethical guidelines" ${ }^{\prime \prime}$.

Although supervisors have an essential impact on the effective provision of services, they receive surprisingly little training in the necessary key skill areas ${ }^{9}$. Training in supervision should focus on the functions of supervision which can be schematically illustrated as shown in Figure 1:

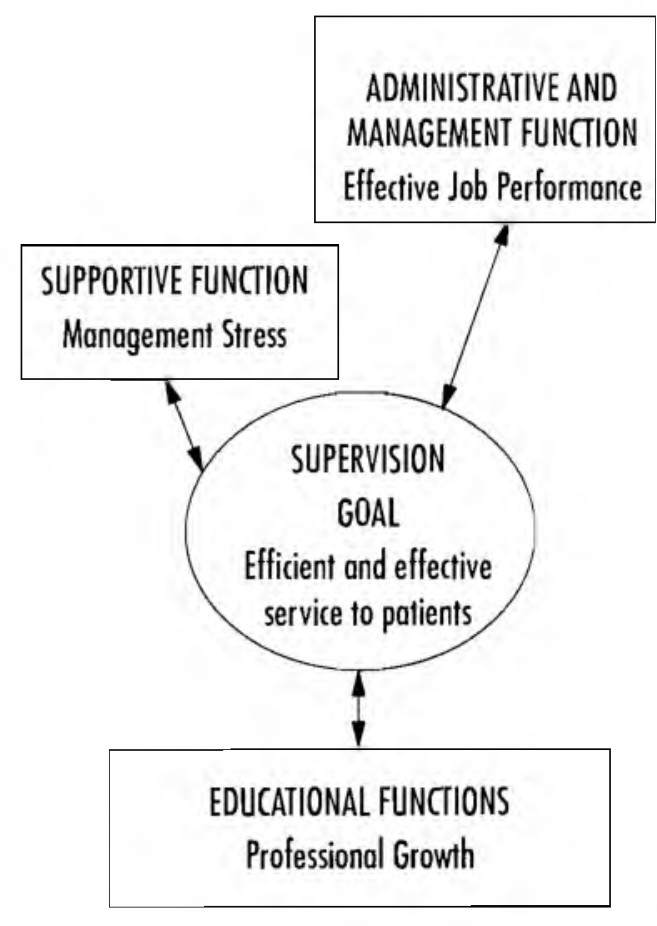

Figure 1. Functions of supervision

\section{SUPPORTIVE FUNCTION}

Supportive supervision includes those activities which identify work related stress and tension and assist employees to deal with these in a mature manner.

The objectives of the supportive function of supervision are:

- to help workers to feel more at ease with themselves in their workplace

- to provide emotional support for the worker

- to encourage, stimulate, and motivate the worker

- to relieve anxiety and dissatisfaction

- to reinforce worker's strengths

- to manage tension arising from job environment.

Workers must feel good about themselves and about their jobs to be able to give an effective service to the patients.

Both the supervisor and supervisee are mutually responsible for identifying sources of job related tensions. These could include lack of knowled ge and skills for a specific task, supervisor/supervisee relationship, vague job descriptions, unrealistic expectations, lack of resources etc.
The techniques which a supervisor could implement to support her or his supervisee include

- reassurance

- encouragement

- recognition of achievement

- expression of confidence and approval

- attentive listening

- pro-active problem solving.

To implement this function of supervision successfully, it is imperative that the supervisor cultivate a positive attitude towards supervision as well as to the supervisee as a person. Another important factor is the commitment to make adequate time available to communicate with the supervisee.

\section{EDUCATIONAL FUNCTION}

"The educational function is concerned with teaching the worker what he needs to know in order to do his job and helping him to learn" ${ }^{3, p 3 y}$.

The total picture of the knowledge, skills and attitude that the supervisee should have in order to perform well can be portrayed in an educational model. The categories in this model include:

Patient: The knowledge, skill and attitude needed to work with patients in a particular section eg. children, the elderly etc.

Place: The knowledge, skill and attitude needed to work in a specific setting such as hospital, institution or community in order to perform her/his duties eg. physical layout, roles of the members of the team etc.

Problem/illness: Knowledge, skill and attitude needed to work with patients or clients suffering from a specific condition.

Process: Refers to the knowledge, skills and attitudes necessary to implement physiotherapy procedures.

Supervisee: Refers to self knowledge and the skills and attitude needed for self-development.

The objectives of this model are to:

- give the supervisee a clear idea of what is expected of her/him

- give direction to the educational programme

- indicate the intensity and extent of educational supervision needed.

Once it has been established what the supervisee must know in order to perform well, it is important to find out what the supervisee already knows and what skills she/he already possesses by doing an educational assessment. The discrepancy between what she/he must know and what she/he already knows will form the content of the educational programme. It follows that this programme will become less intensive as the knowledge and skills of the students, assistants and junior physiotherapists improve.

\section{ADMINISTRATIVE FUNCTION}

"The administrative function is concerned with structuring the work environment and providing the resources which enable the workers to perform their job effectively ${ }^{\prime 3, p 47}$. This refers to the day to day running of a physiotherapy service and would include tasks like the setting of goals, formulation of policies, setting work procedures and standards and evaluation.

Supervisors are normally aware of the administrative tasks expected of them such as staff recruitment and selection; induction in the work place; planning; delegation; monitoring; evaluation and coordination. It is the effectiveness and dedi- 
cation with which these tasks are performed that make the difference in the attitude of the supervisees and the effectiveness of their services.

In the execution of these tasks, the supervisor needs to recognise and implement her/his rights of authority. This right entitles the supervisor to the use of power to exercise control, to make decisions and to demand obedience. By virtue of the supervisor's title, she/he is given positional power to reward (eg. promotions) or to punish (eg. poor evaluation). The supervisee's desire to be liked and respected by the supervisor, affords her/him referent power. Another source of power is the expertise which the supervisor displays in the execution of her tasks.

The supervisor is also the protector of departmental policy and rules and as such she/he needs to exercise the necessary discipline. As health care professionals, physiotherapists find this possibly one of the most difficult tasks to master. Basic principles to bear in mind are:

- to emphasise changing of behaviour instead of punishment

- to be familiar with disciplinary and grievance procedures

- to ensure that all supervisees know the channels to use if they have grievances

- to resolve grievances at the lowest possible level.

One of the most neglected and daunting, yet an extremely important administrative task is the evaluation of staff. An evaluation well done is an excellent tool to facilitate the professional growth of staff members.

This function is seen as a formal and continuous process which should only take place within the context of a positive relationship and should at all times focus on the work and not the person. This process should preview both strengths and weaknesses and objective and specific feedback should be given as soon as possible after the performance. Appropriate feedback can be rewarding and motivating or alternatively a learning and correcting exercise especially if the supervisee has been involved in the process from the beginning.

\section{SUPERVISORY RELATIONSHIP}

The success of supervision depends largely on a positive relationship between the supervisor and the supervisee. This relationship should be characterised by honesty, trust, openness/transparency, participative decision-making, acceptance and mutual respect:

\section{Scheduling}

- Specific, regular appointments at mutually agreed times

- As little disturbance as possible

\section{Preparation}

- Supervisee: Submits some record of his work egr. statistics, notes, problems

- Supervisor: Goes through the items submitted, identifies strengths and problem areas and find relevant reference documents and information.

Review and discuss

- Supervisee: Asks questions, explains, discusses problems and difficulties, relates positive experiences.

- Supervisor: Asks questions, requests clarification, gives support, calls attention to errors, shares relevant knowledge.

Feed back

- Must be specific

- Should be descriptive rather than judgemental

Termination

- Summarise the session

- Organise the next session.

\section{ROLES OF THE SUPERVISOR}

To perform all the functions as described above, the supervisor needs to perform a variety of roles ${ }^{8, p 10}$.

- Advisor/teacher

- Counsellor

- Broker/advocate

- Disciplinarian

- Referral agent

- Career evaluator

- Quality assurance officer

- Organiser of work.

This collection of roles indicates that being a supervisor can be challenging and stimulating because new knowledge and skills have to be developed and the supervisor needs to grow continuously in her/his interaction with the supervisee.

\section{SUMMARY}

The cluster of functions that has been discussed above is generally referred to as "supervision". The word SUPERVISION, in the context of the new SA, often has a negative connotation. The word itself is however, not important but the functions referred to are essential ingredients of personnel management and it can certainly be argued that any worker has a right to be managed in an effective and properly structured manner. The skills required to perform these functions are not normally included in the basic training of a physiotherapist, because "we tend to assume that supervisors, by virtue of their professional knowledge and standing, their seniority and/or their personal maturity are fully capable of the task of supervision"8,p11. Experience however, has shown that additional training and structure are required to prepare the supervisor for her or his multi-role responsibilities regarding supervision for the benefit of the organisation, the patient and the worker.

\section{REFERENCES}

1. The Concise Oxfond Dictionary. Sixuln Edition. Edited by \ B Sykes. Universily Press Oxford, 1976:1160

2. Skidmore R A. Social roork adminishation. Englewood Clifls, NI: Prentice Hall, lnc; 1983:214.

3. Kadushin A. Suprovision in Social Work. New York: Columbia University Press 1985

4. Austin M J. Suprevisory managennent. Englewood Cliffs, NJ: Prentice Halt lnc;1981:11.

5. DuBrin A J. The praction of Supervision. 2nd ed. USA: Business publications lnc;1987:4.

6. Bezuidenhout M, Jonste K. Empowering the Nurse Supervisor. Nirsing RSA 1994:9(7);36.

7. Government Gazette No. 5373, 12 August 1994. Govermment Notice No 1379 .

8. Collins C, Barker $C$. The role of the Supervisor and Training. World Hosputals 1994:30(2);9.

9. Shulman L. Skils of supervision and slaff mumlagment. Itasca, Illinois: FE reacock publishers inc. 1982:1.

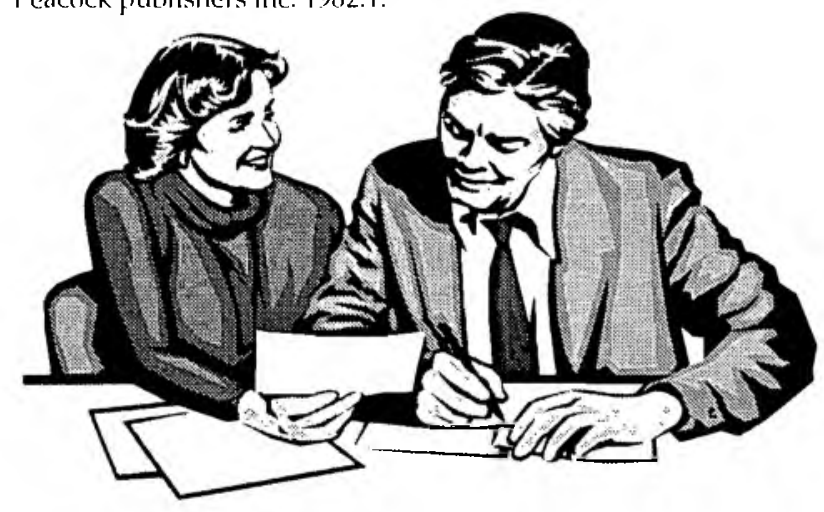

